\title{
APPLICATION OF A CONTROL-MEASURING APPARATUS AND PELTIER MODULES IN THE BULK-METALLIC-GLASS PRODUCTION USING THE PRESSURE-CASTING METHOD
}

\author{
UPORABA KONTROLNO-MERILNE NAPRAVE IN PELTIERJEVIH \\ MODULOV PRI IZDELAVI MASIVNIH KOVINSKIH STEKEL PO \\ POSTOPKU TLAČNEGA LITJA
}

\author{
Wirginia Pilarczyk ${ }^{1}$, Adam Pilarczyk ${ }^{2}$ \\ ${ }^{1}$ Silesian University of Technology, Faculty of Mechanical Engineering, Institute of Engineering Materials and Biomaterials, \\ Konarskiego Street 18a, 44-100 Gliwice, Poland \\ 2Instytut Spawalnictwa, B1. Czesława Street 16-18, 44-100 Gliwice, Poland \\ wirginia.pilarczyk@pols1.pl
}

Prejem rokopisa - received: 2014-07-31; sprejem za objavo - accepted for publication: 2014-09-30

doi:10.17222/mit.2014.140

\begin{abstract}
The primary objective of the article is to present an innovative workstation and the test results related to iron-based bulk metallic glasses made by pressure casting into a copper die that is cooled with Peltier modules. A production of bulk metallic glasses by pressure casting into a copper die, including an innovative cooling method is presented in this article. The equipment for the casting, including a modern high-frequency induction heater and a control-measuring apparatus, which enables the repeatability and maintenance of the process parameters, is discussed. Semiconductor Peltier modules for cooling the molds are presented The tests show that the semiconductor Peltier modules are a suitable substitute for the water cooling of the molds. They enable the casting at $0{ }^{\circ} \mathrm{C}$ of the molds. Additionally, the ecological and economic aspects of the introduced new methods are presented. The application of the innovative cooling technology also has an influence on a simplification of the equipment construction for the casting process. The test results for the bulk metallic glasses based on iron and obtained with the designed devices are presented in this paper. A structure analysis using X-ray examination and microscopic observation was performed The diffraction pattern and microscopic observation revealed that the studied as-cast Fe-Co-B-Si-Nb alloy is in the amorphous state. The test results confirmed the amorphous structure of the obtained materials.

Keywords: metallic materials, bulk metallic glasses, Peltier modules, Fe-based alloy, pressure casting into a copper die
\end{abstract}

Namen tega članka je predstavitev inovativne delovne postaje in rezultatov preizkusov masivnih kovinskih stekel na osnovi železa, izdelanih s tlačnim litjem v bakreno kokilo, hlajeno s Peltierjevimi moduli. V članku je predstavljena izdelava masivnih kovinskih stekel s tlačnim litjem v bakreno orodje z inovativno metodo ohlajanja. Obravnavana je oprema za litje, ki uporablja moderen visokofrekvenčni indukcijski grelnik, opremljen s kontrolno-merilnimi napravami, ki omogočajo ponovljivost in vzdrževanje procesnih parametrov. Predstavljeni so polprevodniški Peltierjevi moduli za hlajenje kokile. Preizkusi so pokazali, da so polprevodniški Peltierjevi moduli primeren nadomestek vodnega hlajenja kokil. Omogočajo ulivanje pri temperaturi kokile $0{ }^{\circ} \mathrm{C}$. Dodatno so predstavljeni še ekološki in ekonomski vidiki nove metode. Uporaba inovativne tehnologije hlajenja vpliva tudi na poenostavitev konstrukcije naprave za ulivanje. V tem delu so predstavljeni rezultati preiskav masivnih kovinskih stekel na osnovi železa, dobljenih z novo konstruirano napravo. Analize strukture so bile izvršene z rentgensko preiskavo. Posnetki difrakcije in mikroskopska opazovanja so odkrila, da je zlitina Fe-Co-B-Si-Nb v litem stanju amorfna. Rezultati preiskav so potrdili amorfno strukturo dobljenega materiala.

Ključne besede: kovinski materiali, masivna kovinska stekla, Peltierjevi moduli, zlitine na osnovi Fe, tlačno litje v bakreno kokilo

\section{INTRODUCTION}

Metallic glasses have an amorphous, i.e., formless structure. This structure is the intermediate between the crystalline and liquid states. In metallic glasses the arrangement of atoms is of a short-range order. Metallic glasses do not have a proper spatial arrangement of all the atoms, which is characteristic of crystals. Amorphous bodies are formed in the conditions of very intense cooling, during which the metallic fluid reaches the solid state without forming the crystalline structure. The positions of atoms are random, which is characteristic of fluids. ${ }^{1,2}$

Bulk metallic glasses (BMGs) have unique physical and mechanical properties. Generally, in some specific cases the properties of metals in the amorphous state are diversified and better than the properties of the crystalline alloys of the same chemical composition. Due to a high chemical uniformity of their structure BMGs are characterised by a very high strength and corrosion resistance. The values of their Young's modulus are similar to those of their crystalline equivalents, yet they do not show the anisotropy of elastic properties and cannot accommodate a plastic strain. Metallic glasses have a lower electrical conductance than the crystalline alloys with the same chemical composition. ${ }^{3}$

The condition for the vitrification of cast metal alloys is cooling at an appropriate very high rate $V_{\mathrm{c}}$. The manufacture of amorphous metal alloys uses specified 
methods. The most popular methods of obtaining bulk metallic glasses include ultrafast splat-cooling, doubleroll casting, laser-spin melting, alloy suction into a copper die or the pressure-casting method. The ultrafast splat-cooling technique consists of ejecting a metallic liquid drop onto a curved copper plate using a pressure shock wave. The pressure shock wave is used to provide the test piece with a specific velocity. This method enables obtaining a cooling rate of $10^{5}-10^{9} \mathrm{~K} / \mathrm{s}$. The effective cooling rate obtained by means of this method depends on the quality of the contact between the metallic liquid and the metal plate. ${ }^{1,4}$

The double-roll casting method consists of cooling a molten drop between two rotating cylinders. In the laser-spin melting method small drops are obtained using a target in the form of a rod rotating at a rate between $8000 \mathrm{r} / \mathrm{min}$ and $30000 \mathrm{r} / \mathrm{min}$. The end of the target is heated using a $\mathrm{CO}_{2}$ laser. According to the reference publications the exemplary cooling rate for $500 \mu \mathrm{m}$ drops amounts to approximately $4000 \mathrm{~K} / \mathrm{s.}^{4}$

The suction of a molten alloy into a copper die is a technique frequently used for cooling alloys in order to obtain bulk metallic glasses. This method consists of the arc melting of an alloy on the surface of a copper crucible with an opening located over the water-cooled copper die. Next, the molten alloy is sucked into the copper die using the pressure difference between a vacuum chamber containing the die and a pump connected to the die bottom. The suction of an alloy into the die was used, among others, for making $\mathrm{Zr}-\mathrm{Cu}-\mathrm{Ni}-\mathrm{Al}$ amorphous rods (30 $\mathrm{mm}$ in diameter and $50 \mathrm{~mm}$ in length) as well as for obtaining the rods (12 $\mathrm{mm}$ in diameter) made of Nd-Fe-Al alloys. ${ }^{1,3}$

The present developmental state of bulk metallic glasses indicates that the nearest future will see further important applications of these materials. Today, bulk metallic glasses are used in the production of, among others, golf clubs, mobile telephones, springs and medical devices. Due to their unique properties bulk metallic glasses are very promising engineering materials.

Presently, in spite of a significant technological progress in the obtainment of amorphous phases, the method of metallic-liquid fast cooling belongs to the most effective methods enabling the production of bulk metallic glasses. It seems that casting by means of fastcooling methods has a future application potential.

The presently used and most frequently described solutions utilise water as the copper-die cooling medium. Such a cooling system functions in an open circulation, i.e., the one in which the die is provided with the cooling water from the central service water system having a temperature between $10{ }^{\circ} \mathrm{C}$ and $20^{\circ} \mathrm{C}$, which, after passing through the die, is carried off to the sewage system. Such a solution, although the simplest, entails numerous inconveniences and limitations, for example, the casting can be performed only in the shops/rooms having access to the central service water system. The process itself requires significant amounts of water. It is not possible to obtain the initial die temperature that is lower than that of the cooling medium.

The first two inconveniences can be eliminated by using a closed cooling system utilising a radiator and circulation-forcing pumps. Irrespective of the environmental conditions and the pump's efficiency, the cooling-medium temperature cannot be significantly reduced anyway, which is a significant limitation of this type of system.

Because of this, the authors of the article commenced a search for and an investigation on alternative sources of cooling a copper die used for casting metallic glasses.

The use of one of the basic thermoelectric phenomena, i.e., the Peltier effect has enabled the development of an innovative cooling system.

The Peltier effect is based on the phenomenon of the current-flow-induced change in the temperature at the junction of alternately arranged " $\mathrm{n}$ " and "p" semiconductors made of appropriately antimony- and seleniumdoped bismuth telluride.

The tests involved the construction of a device presented in Figure 1, utilising the Peltier modules for copper-die cooling. The copper die with appropriately prepared grooves giving the right shape to the cast elements was composed of two parts being the mirror reflections of each other. The modules $(100 \mathrm{~W})$ required the use of radiators and fans on their hot sides. The efficiency of the radiators and fans significantly affected the die temperature. The configuration of the radiators and fans in the model device enabled obtaining the die temperature between ten and twenty degrees Celsius below zero at ambient room temperature. As a result, it was possible to obtain a significantly lower initial die temperature.

The main goal of the article is to describe the innovative equipment and present the test results for Fe-based bulk metallic glasses.

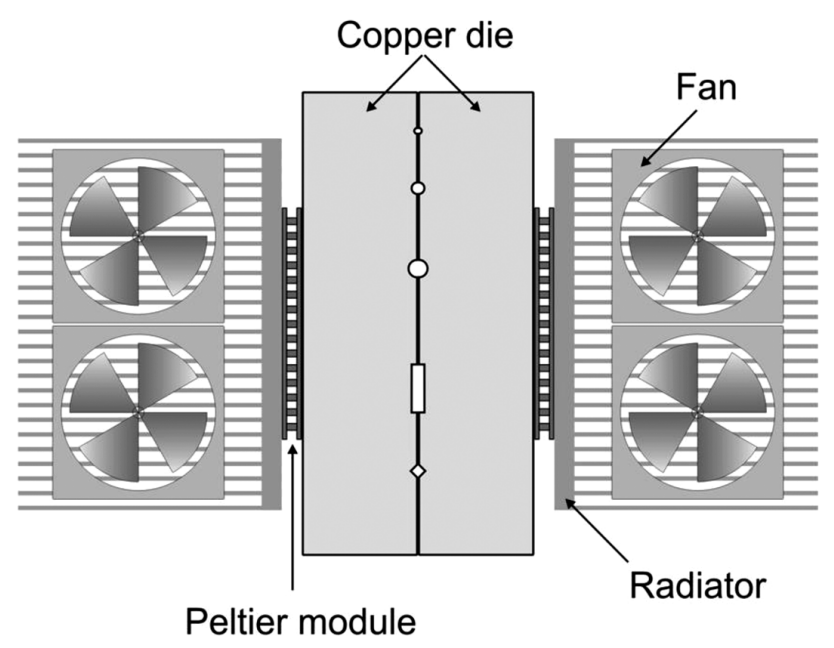

Figure 1: Scheme of the pressure-casting die with Peltier modules Slika 1: Shematski prikaz orodja za tlačno litje s Peltierjevimi moduli 


\section{TEST PROCEDURE}

\subsection{Test material}

The material used in the tests was an alloy based on the iron matrix of the Fe-Co-B-Si-Nb system. An ingot with a pre-defined $\left(\mathrm{Fe}_{37.44} \mathrm{Co}_{34.56} \mathrm{~B}_{19.2} \mathrm{Si}_{4.8} \mathrm{Nb}_{4.0}\right)$ chemical composition was prepared by induction melting highpurity component elements $\mathrm{Fe}, \mathrm{Co}, \mathrm{B}, \mathrm{Si}$ and $\mathrm{Nb}$ in a nitrogen atmosphere. The ingot with a homogenous structure underwent refining and remelting in a quartz crucible using an induction coil. Afterwards, the preliminary alloy was cast into the copper die using pressurised argon. As a result, rods with diameters of 1.5 $\mathrm{mm}$ and $3.0 \mathrm{~mm}$ were obtained.

Scheme of the station for making bulk metallic glasses is presented in Figure 2.

In order to carry out a technological process ensuring the test repeatability, the test station was provided with a necessary control-measuring apparatus. The module solutions supported by the LabView hardware and software, developed by National Instruments, enabled us to design a proper configuration of the related test station. The appropriate selection of the measurement modules integrated in a single housing as well as the possibility of controlling the modules using the LabView environment software ensured a failure-free and stable test-station operation and a relatively easy configuration modification.

\subsection{Testing methods}

Testing the structures of the elements made involved systematic tests of the phase composition $\mathrm{Fe}_{37.44} \mathrm{Co}_{34.56} \mathrm{~B}_{19.2} \mathrm{Si}_{4.8} \mathrm{Nb}_{4.0}$ of the bulk metallic alloys in the form of rods. The tests utilised a Seifert-FPMmanufactured XRD 7 X-ray diffractometer provided with an X-ray lamp with a Co anode. The X-ray lamp voltage-current operational parameters amounted to $35 \mathrm{kV}$ and $25 \mathrm{~mA}$, respectively.

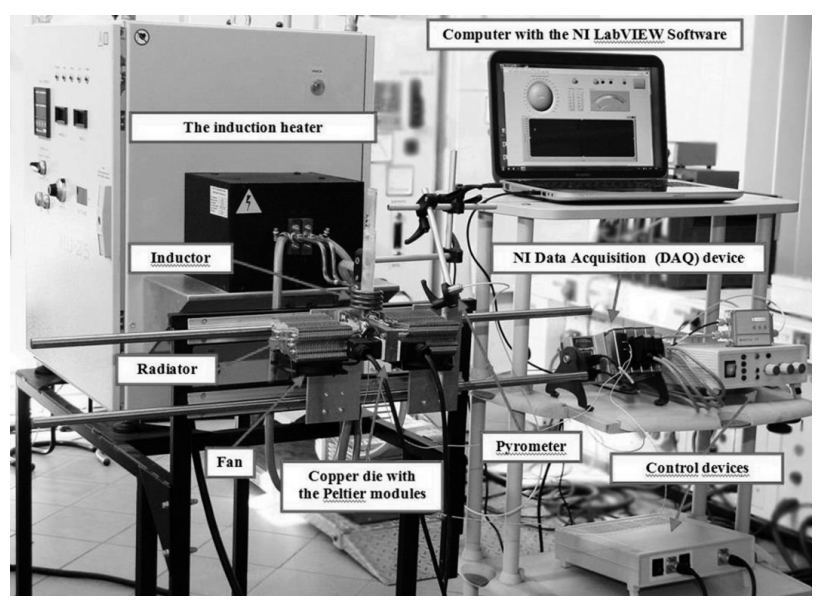

Figure 2: Scheme of the station for making bulk metallic glasses Slika 2: Prikaz postaje za izdelavo masivnih kovinskih stekel

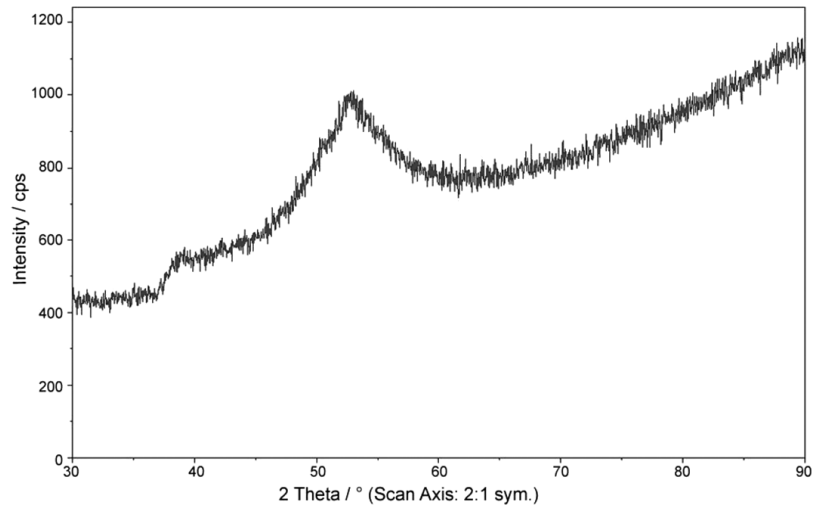

Figure 3: X-ray diffraction pattern of the $\mathrm{Fe}_{37.44} \mathrm{Co}_{34.56} \mathrm{~B}_{19.2} \mathrm{Si}_{4.8} \mathrm{Nb}_{4.0}$ alloy rod with a diameter of $1.5 \mathrm{~mm}$

Slika 3: Rentgenska difrakcija zlitine $\mathrm{Fe}_{37,44} \mathrm{Co}_{34,56} \mathrm{~B}_{19,2} \mathrm{Si}_{4,8} \mathrm{Nb}_{4,0} \mathrm{v}$ obliki palice premera $1,5 \mathrm{~mm}$

The observations of the microstructure of the bulk metallic glasses obtained using pressure casting into the water-cooled copper die utilising the Peltier modules were performed with a Zeiss-manufactured Supra 25 scanning electron microscope provided with an X-ray microanalysis attachment.

\section{TEST RESULTS AND DISCUSSION}

Figures 3 and 4 present the $\mathrm{X}$-ray examination results for the $\mathrm{Fe}_{37.44} \mathrm{Co}_{34.56} \mathrm{~B}_{19.2} \mathrm{Si}_{4.8} \mathrm{Nb}_{4.0}$ alloy rods. The analysis of X-ray spectra revealed a fully amorphous structure. A significant thickness value for a fully amorphous test piece indicates a good vitrification capacity of the alloy and properly adjusted and applied bulkmetallic-glass manufacturing conditions. The X-ray diffraction patterns revealed single low-intensity diffuse reflexes confirming the formation of an amorphous structure. The presence of nanocrystallites can be confirmed by means of a high-resolution electron microscope, yet this was not the primary objective of this work.

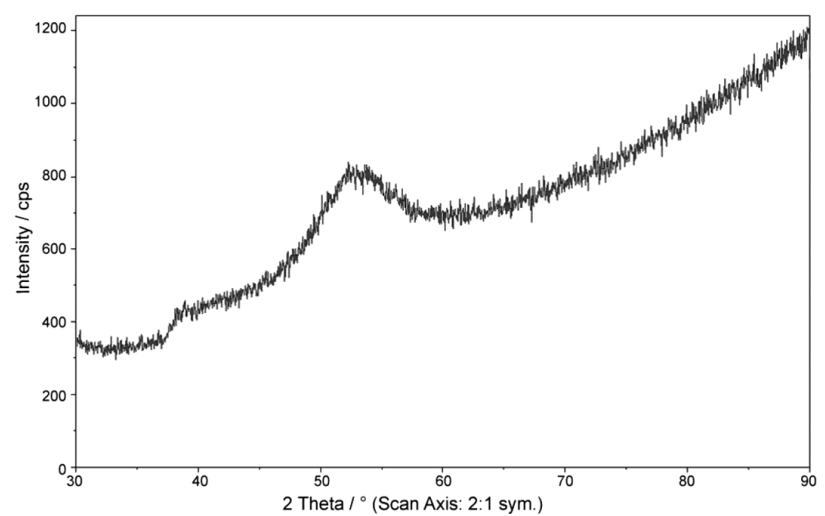

Figure 4: $\mathrm{X}$-ray diffraction pattern of the $\mathrm{Fe}_{37.44} \mathrm{Co}_{34.56} \mathrm{~B}_{19.2} \mathrm{Si}_{4.8} \mathrm{Nb}_{4.0}$ alloy rod with a diameter of $3 \mathrm{~mm}$

Slika 4: Rentgenska difrakcija zlitine $\mathrm{Fe}_{37,44} \mathrm{Co}_{34,56} \mathrm{~B}_{19,2} \mathrm{Si}_{4,8} \mathrm{Nb}_{4,0} \mathrm{v}$ obliki palice premera $3 \mathrm{~mm}$ 


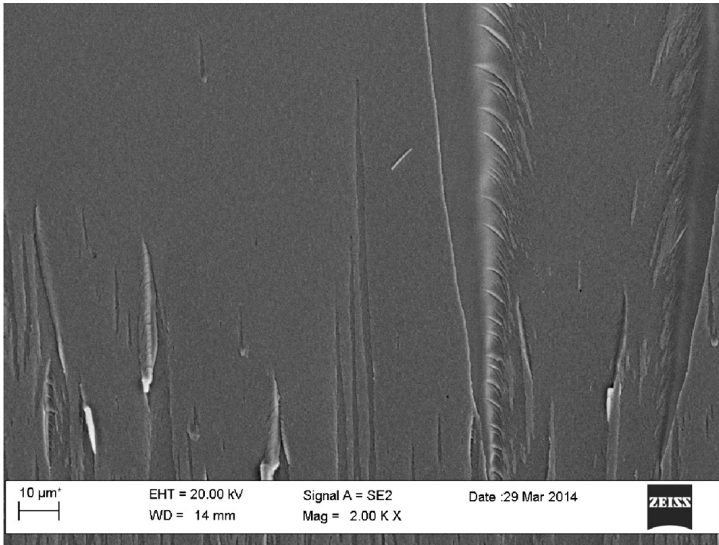

Figure 5: SEM micrograph of the fracture morphology of $\mathrm{Fe}_{37.44} \mathrm{Co}_{34.56} \mathrm{~B}_{19.2} \mathrm{Si}_{4.8} \mathrm{Nb}_{4.0}$ amorphous rod in the as-cast state with a diameter of $1.5 \mathrm{~mm}$

Slika 5: SEM-posnetek morfologije preloma amorfne palice $s$ premerom $1,5 \mathrm{~mm} \quad \mathrm{v}$ litem stanju iz zlitine $\mathrm{Fe}_{37,44} \mathrm{Co}_{34,56} \mathrm{~B}_{19,2} \mathrm{Si}_{4,8} \mathrm{Nb}_{4,0}$

Figures 5 and 6 present the test-piece fractures formed during the bending of the $\mathrm{Fe}_{37.44} \mathrm{Co}_{34.56} \mathrm{~B}_{19.2} \mathrm{Si}_{4.8} \mathrm{Nb}_{4.0}$ alloy rods. The microscopic examination revealed smooth inner surfaces of the test pieces. The smooth mirror-like fracture surfaces confirmed the presence of the amorphous state. In addition, on the surface of the amorphous test-piece fracture it was possible to observe the so-called "veiny patterns", being the characteristic elements of a ductile fracture, typical of the materials with an amorphous (formless) structure. It is justified to suppose that in the case of a crystalline-structure material the fracture surface would be rough.

The alloys were also checked with EDS to identify the chemical compositions of chosen areas. The chemical analysis of these areas show the presence of the Fe, $\mathrm{Co}, \mathrm{B}, \mathrm{Si}$, and $\mathrm{Nb}$ elements. The curves of the X-ray dis-

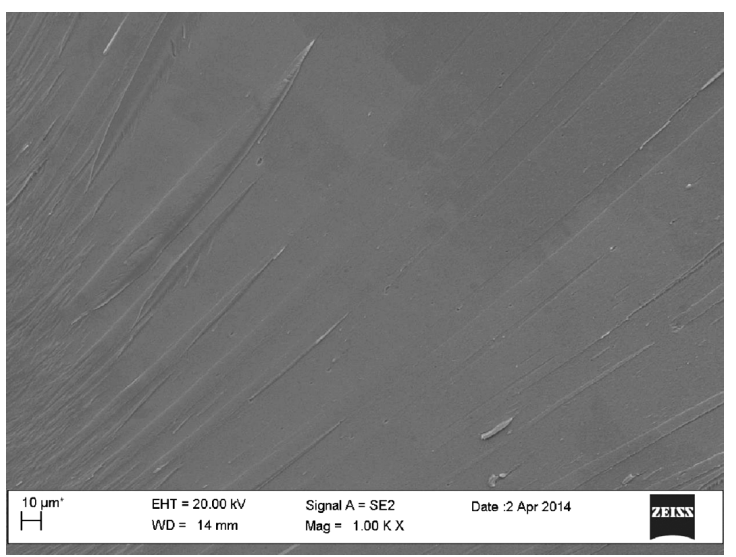

Figure 6: SEM micrograph of the fracture morphology of $\mathrm{Fe}_{37.44} \mathrm{Co}_{34.56} \mathrm{~B}_{19.2} \mathrm{Si}_{4.8} \mathrm{Nb}_{4.0}$ amorphous rod in the as-cast state with a diameter of $3 \mathrm{~mm}$

Slika 6: SEM-posnetek morfologije preloma amorfne palice $s$ premerom $3 \mathrm{~mm}$ v litem stanju iz zlitine $\mathrm{Fe}_{37,44} \mathrm{Co}_{34,56} \mathrm{~B}_{19,2} \mathrm{Si}_{4,8} \mathrm{Nb}_{4,0}$

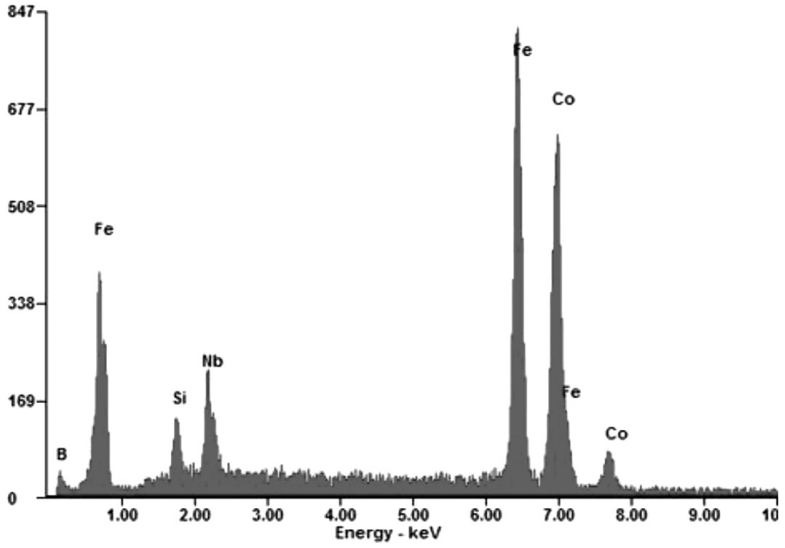

Figure 7: Plot of the $\mathrm{X}$-ray dispersive-energy spectrometer measurement of the $\mathrm{Fe}_{37.44} \mathrm{Co}_{34.56} \mathrm{~B}_{19.2} \mathrm{Si}_{4.8} \mathrm{Nb}_{4.0}$ alloy in the as-cast state with a diameter of $1.5 \mathrm{~mm}$ (the area from Figure 5)

Slika 7: Diagram rentgenske disperzije zlitine $\mathrm{Fe}_{37,44} \mathrm{Co}_{34,56} \mathrm{~B}_{19,2} \mathrm{Si}_{4,8} \mathrm{Nb}_{4,0} \mathrm{v}$ litem stanju premera $1,5 \mathrm{~mm}$ (področje s slike 5)

persive analysis of the $\mathrm{Fe}_{37.44} \mathrm{Co}_{34.56} \mathrm{~B}_{19.2} \mathrm{Si}_{4.8} \mathrm{Nb}_{4.0}$ alloys are presented in Figures $\mathbf{7}$ and $\mathbf{8}$.

The alloy vitrification capacity is of critical importance when obtaining materials with amorphous structures. Another, equally important factor, is the critical cooling rate obtained with the manufacturing method applied. In order to obtain a fully amorphous test-piece structure it is necessary to use highly advanced, fast cooling techniques utilising the radial-heat offtake from the metal volume. Due to the significant geometrical dimensions of the test pieces, the cooling rates of the methods utilising the radial-heat offtake are lower than those achieved while making classical metallic glasses in the form of bands with thicknesses of several $m \mu$. The bulk-metallic-glass production technology usually involves the use of water-cooled copper dies. For this reason, the objectives of this work were to present a

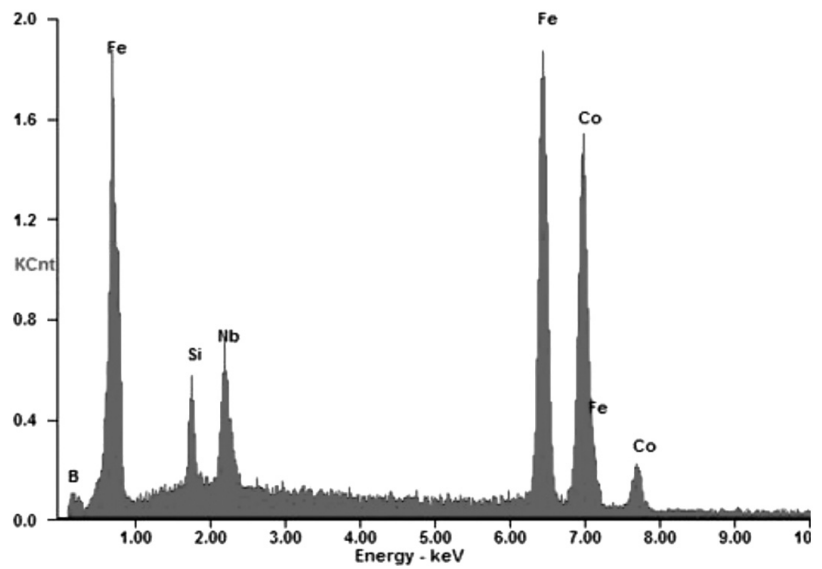

Figure 8: Plot of the X-ray dispersive-energy spectrometer measurement of the $\mathrm{Fe}_{37.44} \mathrm{Co}_{34.56} \mathrm{~B}_{19.2} \mathrm{Si}_{4.8} \mathrm{Nb}_{4.0}$ alloy in the as-cast state with a diameter of $3 \mathrm{~mm}$ (the area from Figure 6)

Slika 8: Diagram rentgenske disperzije zlitine $\mathrm{Fe}_{37,44} \mathrm{Co}_{34,56} \mathrm{~B}_{19,2} \mathrm{Si}_{4,8} \mathrm{Nb}_{4,0} \mathrm{v}$ litem stanju premera $3 \mathrm{~mm}$ (področje $\mathrm{s}$ slike 6) 
station and determine the copper-die cooling capacity using the Peltier modules as well as to present the test results for the bulk metallic glasses confirming their amorphous structure.

\section{CONCLUSIONS}

- Test pieces in the form of rods $(1.5 \mathrm{~mm}$ and $3 \mathrm{~mm}$ in diameter) were made by pressure casting an ironbased alloy into a copper die in argon atmosphere.

- X-ray diffractions and a microscopic examination revealed that it is possible to make iron-based bulk metallic glasses in the form of rods using the pressure-casting procedure involving an innovative casting-die cooling method.

- The use of the innovative cooling system based on thermoelectric Peltier modules enabled us to obtain the initial die temperature that was considerably lower than that obtained previously, using the water-based cooling solution. As a result, the cooling process was accelerated.

- In addition, the cooling system described above is environmentally friendly as it allows us to limit (eliminate) the water consumption. The current necessary for obtaining the minimum temperature is 10-20 W h.

- The apparatus design and the casting-die cooling method involving the Peltier modules are the subjects of a patent application filed at the Polish Patent Office, the patent-application title being: Forma odlewnicza i sposób chłodzenia formy odlewniczej zwłaszcza do wytwarzania prętów i płytek z materiałów metalowych (Nr UP P.405786) /Casting Die and Casting Die Cooling Method Intended for Making Rods and Plates of Metallic Materials/.

\section{Acknowledgement}

This project was funded by the National Science Centre on the basis of decision DEC-2011/01/D/ST8/ 07327.

\section{REFERENCES}

${ }^{1}$ C. Suryanarayana, A. Inoue, Bulk metallic glasses, CRC Press, Taylor \& Francis Group, 2011

${ }^{2}$ W. Pilarczyk, J. Podwórny, The study of local structure of amorphous $\mathrm{Fe}-\mathrm{Co}-\mathrm{B}-\mathrm{Si}-\mathrm{Nb}$ alloy by atomic pair distribution function, Solid State Phenomena, 203-204 (2013), 386-389, doi:10.4028/ www.scientific.net/SSP.203-204.386

${ }^{3}$ K. Kurzydłowski, M. Lewandowska, Engineering Construction and Functional Nanomaterials, PWN, Warszawa 2010, 28-30 (in Polish)

${ }^{4} \mathrm{~K}$. Ziewiec, Metallic glasses obtained from homogeneous liquid phase and immiscibility range of liquid, Scientific Publishers of Pedagogic University, Kraków 2011, 28-33 (in Polish) 